\title{
ESSENTIAL OIL AND TRICHOME DENSITY FROM Origanum majorana L. SHOOTS AFFECTED BY LEAF AGE AND SALINITY
}

\author{
ÓLEO ESSENCIAL E DENSIDADE DO TRICOMA DOS REBENTOS DA Origanum \\ majorana L. AFETADOS PELA IDADE DA FOLHAGEM E PELA SALINIDADE
}

\author{
Baâtour Olfa ${ }^{1}$, Tarchoune Imen ${ }^{1}$, Zaghdoudi Maha ${ }^{1}$, Chebbi Mohamed ${ }^{1}$, Ben Nasri-Ayachi $\mathbf{M}^{\mathbf{1}}$ \\ 1.Unité de Physiologie et Biochimie de la Tolérance aux contraintes Abiotiques des Plantes, Département de \\ Biologie, Faculté des Sciences de Tunis, Campus Universitaire, 2092 Tunis, Tunisie. olfa_zouhair@yahoo.fr; \\ baatourolfanaiimi@gmail.com
}

\begin{abstract}
Essential oil (EO) from Origanum majorana L. (Lamiaceae) shoots, extracted by hydrodistillation from plant cultivated under control and salt conditions. Essential oil composition was determined by GCMS. Plant material was harvest at three vegetative stages; early (EVS), late (LVS) and early flowering (P.F.S). Essential oil yield were $0.11 \%$ and 0.071 for E.V.S, $0.19 \%$ to $0.37 \%$ for L.V.S $0.23 \%$ and $0.47 \%$ for P.F.S, at the control and in the presence of $75 \mathrm{mM} \mathrm{NaCl}$, respectively. Salt stress and development of vegetative stage affected the formation of the major compounds: cis-sabinene hydrate and terpinene-4-ol. Leaves were observed with scanning electron microscope (SEM), to determined trichomes number, size and distribution. Results showed that globular trichome density decrease with leaf maturity but increased with salinity.
\end{abstract}

KEYWORDS: Essential oil. Origanum majorana L. Salinity. Trichomes.

\section{INTRODUCTION}

Glandular and non glandular trichomes are known to be present on the surfaces of leaves (BAATOUR et al. 2012). Previous reports have shown that there are glandular and non glandular trichomes that function in plants to protect it. It seemed that under salinity, leaves are more involved in essential oil production (BAATOUR et al. 2012). Number of environmental conditions factors have high impact on the performance of plant including EO content and composition (FAROOQI et al. 1999).

Salinity is one of the major factors that affect essential oil biosynthesis and secretion (HEUER et al. 2002). In Tunisia, salt-affected soils cover about $10 \%$ of the total area of the country (HACHICHA, 2007). Thus it is important to consider this factor in every study. Lamiaceae is the important family of aromatic and medicinal plant, it is known for its popular species such as, basil, lavender, thyme or clary sage (Salvia sclarea) and oregano. Among this later genus Origanum majorana Syn. Majorana hortensis (M.), is one of the most common medicinal and aromatic species in Tunisia. Its essential oil was known for its antimicrobial (MOHAMMED et al. 2011), antimutagenic (AL-HARBI, 2011) antihyperglycemic, antilipidemic (AL-HARBI, 2011) and antiulcer (PIMPLE et al. 2012) and antioxidant activity (BAATOUR et al. $2012 \mathrm{c}$ ). It is used in perfumery for its spicy fragrance and herbaceous notes (FILIPPO et al.2000). Origanum majorana L., as described by Wagner et al. (2004) in most Lamiaceae species, we have observed epidermal trichomes in leaves and stems. Trichomes were divided into two subcategories, glandular and non-glandular (BAATOUR et al. 2012). Three type of EO secretion referred to their contrast dark red droplets, clear lipids droplets, secretion of lucid appearance were seen under cuticule of head cells of peltate trichomes (BAATOUR et al. 2012). Many phytochemical studies have been conducted to investigate the chemical composition of Origanum majorana L. In our knowledgment, there is no study in salt effect on: i) glandular distribution, ii) EO content and composition at development staged. Except study of Karray et al. (2009) in Mentha Pulegium, who reported that under saline condition, glandular trichomes exhibited no visible reduction in their sizes, maintained the same distribution between leaf sides in young as well as in mature leaves. But, there is an increased in the densities of the two types of glandular trichomes (peltate and capitate). That's why in the present work we investigate, the effect of salinity on Tunisian $O$. majorana shoot essential oil content at three development stage, and we explained to understand the phenomenon through a study concerning trichomes distribution under saline and non-saline conditions. 


\section{MATERIAL AND METHODS}

\section{Plant material}

Marjoram seeds (collected in 2010) were taken from a local plant nursery at Nabeul in Northeast of Tunisia. Plants of $O$. majorana were raised from seed for 8 days in a culture chamber

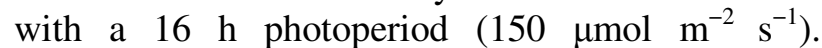
Temperature and average relative moisture were 22 ${ }^{\circ} \mathrm{C}$ and $40 \%$, respectively, during the day and $18^{\circ} \mathrm{C}$ and $86 \%$ at night. Plants were transferred to eightstrength Hoagland and Arnon (1950) nutrient solution $\left(1.25 \mathrm{mmol} \mathrm{L} \mathrm{L}^{-1} \mathrm{KNO}_{3}, 1.25 \mathrm{mmol} \mathrm{L}{ }^{-1} \mathrm{Ca}\right.$ $\left(\mathrm{NO}_{3}\right)_{2} .4 \mathrm{H}_{2} \mathrm{O}, 0.50 \mathrm{mmol} \mathrm{L} \mathrm{L}^{-1} \mathrm{MgSO}_{4} .7 \mathrm{H}_{2} \mathrm{O}, 0.25$ mmol L ${ }^{-1} \mathrm{KH}_{2} \mathrm{PO}_{4}, 0.01 \mathrm{mmol} \mathrm{L} \mathrm{L}^{-1} \mathrm{H}_{3} \mathrm{BO}_{3}, 0.001$ $\mathrm{mmol} \mathrm{L}^{-1} \quad \mathrm{MnSO}_{4} .4 \mathrm{H}_{2} \mathrm{O}, 0.0005 \mathrm{mmol} \mathrm{L}^{-1}$ $\mathrm{CuSO}_{4} .5 \mathrm{H}_{2} \mathrm{O}, 0.0005 \mathrm{mmol} \mathrm{L}^{-1} \mathrm{ZnSO}_{4} .6 \mathrm{H} 2 \mathrm{O}$ and $\left.0.00005 \mathrm{mmol} \mathrm{L}^{-1}\left(\mathrm{NH}_{4}\right)_{6} \mathrm{Mo}_{7} \mathrm{O}_{24} .4 \mathrm{H}_{2} \mathrm{O}\right)$ in a culture chamber with a $16 \mathrm{~h}$ photoperiod $\left(150 \mu \mathrm{mol} \mathrm{m} \mathrm{m}^{-2}\right.$ $\left.\mathrm{s}^{-1}\right)$. After 20 days of acclimation, $\mathrm{NaCl}(75 \mathrm{mmol}$ $\mathrm{L}^{-1}$ ) was added to the nutritive solution. The plant aerial parts were harvested 17, 24 and 31 respectively at early (EVS), late (LVS) and preflowering vegetative stage (PFS).

\section{Essential oil isolation, identification and quantification \\ Isolation}

A $50 \mathrm{~g}$ portion of air-dried material was subjected to hydrodistillation for $90 \mathrm{~min}$ in a simple laboratory according to Msaada et al. (2007). Quikfit apparatus consisting of a $1 \mathrm{~L}$ steam generator flask, a distillation flask, a condenser and a receiving vessel. The obtained distillate was extracted using diethyl ether as solvent and dried over anhydrous sodium sulfate. The organic layer was then concentrated at $35^{\circ} \mathrm{C}$ in a Vigreux column and the essential oil was stored at $-20^{\circ} \mathrm{C}$ until analysis. In order to quantify the essential oil constituents, 6- methyl-5-hepten-2-one was used as an internal standard. Essential oil isolation was done in triplicate.

\section{Identification and quantification}

GC-FID: Gas chromatography analysis was carried out on a Hewlett-Packard 6890 gas chromatograph equipped with a flame ionization detector (FID) and an electronic pressure control (EPC) injector. A polar HP Innowax (PEG) column and an apolar HP-5 column $(30 \mathrm{~m} \times 0.25 \mathrm{~mm}, 0.25$ $\mu \mathrm{m}$ film thickness) were used. The carrier gas $\left(\mathrm{N}_{2}\right.$, U) flow was $1.6 \mathrm{ml} \mathrm{min}^{-1}$ and the split ratio 60:1. $\mathrm{EO}$ analysis was performed using the following temperature program: oven temps isotherm at $35^{\circ} \mathrm{C}$ for $10 \mathrm{~min}$, from 35 to $205^{\circ} \mathrm{C}$ at the rate of $3^{\circ} \mathrm{C}$ min-
1 and isotherm at $225^{\circ} \mathrm{C}$ during $10 \mathrm{~min}$. Injector and detector temperatures, were held, respectively at 250 and $300^{\circ} \mathrm{C}$.

GC-MS: GC-MS analysis was performed on a gas chromatograph HP 5890 (II) interfaced with a HP 5972 mass spectrometer with electron impact ionization $(70 \mathrm{eV})$. A HP-5MS capillary column $(30 \mathrm{~m} \times 0.25 \mathrm{~mm}, 0.25 \mu \mathrm{m}$ film thickness) was used. The column temperature was programmed to rise from 50 to $240^{\circ} \mathrm{C}$ at a rate of $5^{\circ} \mathrm{C} \min ^{-1}$. The carrier gas was helium with a flow rate of $1.2 \mathrm{ml} \mathrm{min}^{-1}$; split ratio was $60: 1$. Scan time and mass range were $1 \mathrm{~s}$ and $40-300 \mathrm{~m} / \mathrm{z}$, respectively (Baatour et al. 2010).

\section{Scanning electron microscopy (SEM)}

Leaves from the top (third node from the apex) and the base (tenth node from the apex) of control and treated plants were harvest for each treatment, without causing any damage to the surfaces, 10 fresh leaves were observed on the two faces by a FEIQUANTA 200 environmental scanning microscope.

\section{Statistical analysis}

All data were subjected to analyses of variance and means were separated using Duncan's multiple range test at a $5 \%$.

\section{RESULT AND DISCUSSION}

Variation of essential oil yield and composition with leaf age and salinity

Essential oil (EO) yields from O. majorana shoots, varied with stages (Table.1). In the control, EO yield increased by about 1.61 times and 2.32 times respectively at L.V.S and P.F.S. as compared to EVS (Table. 1). At $75 \mathrm{mM} \mathrm{NaCl}$, this yield decreased significantly by about 0.6 times at EVS, but increased by about 1.94 and 2 times at L.V.S. and P.F.S., respectively. The increase at LVS was in agreement of most previous works such as those of Verdian-Rizi (2008) in Origanum onites and Laurus nobilis; Karray et al. (2009) in Mentha pulegium and Hamrouni et al. (2009) in Origanum majorana. This decrease in EO yield may be due to the low rate of biosynthesis of volatile compounds during vegetative stage and suggest biosynthesis of volatile compounds that to reach a maximum during the pre flowering stage. At our knowledgment this stage could be favoured to ensure the maximum of essential oil yield. EO composition is affected by many factors, among others, the development stage (KIM; LEE, 2004). 
Table 1. Quantitative ( $\mu \mathrm{g} / \mathrm{g} \mathrm{DW})$ changes of essential oil compounds from Origanum majorana shoots under $\mathrm{NaCl} 75 \mathrm{mM}$ at the early vegetative stage (E.V.S), late vegetative stage (L.V.S) and preflowering stage (P.F.S.)

\begin{tabular}{|c|c|c|c|c|c|c|}
\hline \multirow{2}{*}{\multicolumn{3}{|c|}{ Essential oil yield (\%) }} & L.V.S & L.V.S & P.F.S & P.F.S \\
\hline & & & $0.19 \pm 0.002^{b}$ & $0.37 \pm 0.005^{\mathrm{a}}$ & $0.232 \pm 0.024^{b}$ & $0.479 \pm 0.005^{\mathrm{a}}$ \\
\hline \multirow[t]{2}{*}{ Compounds } & \multirow[t]{2}{*}{$\mathbf{R \mathbf { I } ^ { \mathrm { a } }}$} & \multirow[t]{2}{*}{$\mathbf{R I}^{\mathbf{b}}$} & \multicolumn{4}{|c|}{ Content of total volatiles $(\mu \mathrm{g} / \mathrm{g}$ DW) } \\
\hline & & & 0 (control) & 75 & 0 (control) & 75 \\
\hline Toluene & & & - & $0.006^{\mathrm{a}}$ & $0.023 \pm 0.01^{b}$ & $0.031 \pm 0.01^{b}$ \\
\hline Tricyclene & 927 & 1014 & - & - & $0.006 \pm 0.00^{\mathrm{b}}$ & $0.035 \pm 0.02^{\mathrm{a}}$ \\
\hline$\alpha$-pinene & 931 & 1035 & $0.09 \pm 0.03^{\mathrm{a}}$ & $0.001 \pm 0.01^{\mathrm{b}}$ & $0.017 \pm 0.00^{\mathrm{b}}$ & $0.719 \pm 0.24^{\mathrm{a}}$ \\
\hline$\beta$-pinene & 980 & 1095 & - & $0.012 \pm 0.03^{\mathrm{a}}$ & $0.26 \pm 0.14^{\mathrm{b}}$ & $0.404 \pm 0.04^{\mathrm{a}}$ \\
\hline sabinene & 976 & 1132 & $9.75 \pm 0.87^{\mathrm{a}}$ & $0.034 \pm 0.23^{b}$ & $1.41 \pm 0.03^{\mathrm{b}}$ & $0.374 \pm 0.04^{\mathrm{a}}$ \\
\hline$\Delta$-3-Carene & 1014 & 1134 & - & $0.010 \pm 0.08^{\mathrm{a}}$ & $0.01 \pm 0.00^{\mathrm{b}}$ & $4.04 \pm 0.23^{\mathrm{a}}$ \\
\hline myrcene & 991 & 1174 & $0.06 \pm 0.10^{\mathrm{b}}$ & $0.015 \pm 0.21^{\mathrm{a}}$ & $0.19 \pm 0.24^{b}$ & $0.041 \pm 0.24^{\mathrm{b}}$ \\
\hline myrtenal & 1192 & 1684 & - & $0.077 \pm 0.10^{\mathrm{a}}$ & $1.1 \pm 0.24^{\mathrm{b}}$ & $0.039 \pm 0.24^{\mathrm{b}}$ \\
\hline$\alpha$ phellandrene & 1006 & 1176 & - & - & - & - \\
\hline limonene & 1030 & 1203 & - & - & $3.74 \pm 0.22^{\mathrm{a}}$ & - \\
\hline 1.8 cineole & 1033 & 1213 & - & $0.002 \pm 0.02^{\mathrm{a}}$ & $0.83 \pm 0.12^{\mathrm{b}}$ & $9.95 \pm 1.12^{\mathrm{a}}$ \\
\hline$\gamma$-terpinene & 1062 & 1266 & $0.63 \pm 0.10^{\mathrm{a}}$ & $0.003 \pm 0.04^{b}$ & $0.05 \pm 0.01^{\mathrm{b}}$ & $0.07 \pm 0.01^{\mathrm{a}}$ \\
\hline p-cymene & 1026 & 1280 & - & $0.04 \pm 0.23^{\mathrm{a}}$ & - & - \\
\hline terpinolene & 1088 & 1290 & $0.14 \pm 0.10^{b}$ & $0.03 \pm 0.10^{\mathrm{a}}$ & $1.46 \pm 0.1^{\mathrm{b}}$ & $7.45 \pm 0.21^{\mathrm{a}}$ \\
\hline cis p-menth-en-1-ol & 1129 & 1562 & $0.11 \pm 0.01^{\mathrm{a}}$ & $0.001 \pm 0.00^{b}$ & $0.081 \pm 0.01^{\mathrm{b}}$ & $0.09 \pm 0.001^{\mathrm{a}}$ \\
\hline B-tujone & 1115 & 1336 & - & $0.002 \pm 0.02^{\mathrm{a}}$ & $0.068 \pm 0.01^{\mathrm{b}}$ & $12.96 \pm 0.45^{\mathrm{a}}$ \\
\hline trans p-menth-en-1-ol & 1130 & 1638 & $3.63 \pm 0.87^{\mathrm{a}}$ & $0.019 \pm 0.14^{\mathrm{b}}$ & $5.97 \pm 0.24^{\mathrm{a}}$ & - \\
\hline Linalool & 1098 & 1553 & $0.11 \pm 0.10^{\mathrm{a}}$ & $0.003 \pm 0.01^{\mathrm{a}}$ & $0.107 \pm 0.01^{\mathrm{b}}$ & $25.19 \pm 0.31^{\mathrm{a}}$ \\
\hline camphor & 1143 & 1532 & - & $0.004 \pm 0.07^{\mathrm{a}}$ & $0.016 \pm 0.01^{\mathrm{b}}$ & $0.289 \pm 0.04^{\mathrm{a}}$ \\
\hline$\beta$ murolene & 1469 & 1672 & - & $0.001 \pm 0.00^{\mathrm{a}}$ & 0.130 & 0.06 \\
\hline cis sabinene hydrate & 1082 & 1556 & $16.33 \pm 0.10^{\mathrm{a}}$ & $0.90 \pm 0.08^{b}$ & $20.32 \pm 0.19^{\mathrm{a}}$ & $68.85 \pm 0.27^{\mathrm{a}}$ \\
\hline trans sabinene hydrate & 1053 & 1474 & $1.07 \pm 0.05^{b}$ & $0.18 \pm 1.98^{\mathrm{a}}$ & $2.09 \pm 0.11^{\mathrm{b}}$ & $6.13 \pm 0.31^{\mathrm{a}}$ \\
\hline linalyl acetate & 1257 & 1556 & 0.18 & $0.11 \pm 0.25^{\mathrm{a}}$ & $0.53 \pm 0.11^{\mathrm{b}}$ & $1.39 \pm 0.02^{\mathrm{a}}$ \\
\hline bornyl acetate & 1295 & 1597 & $0.71 \pm 0.01^{\mathrm{b}}$ & $0.03 \pm 0.13^{\mathrm{a}}$ & $1.32 \pm 0.02^{\mathrm{a}}$ & $4.02 \pm 0.31^{\mathrm{a}}$ \\
\hline Carvone & 1245 & 1598 & - & - & - & - \\
\hline$\beta$-elemene & 1391 & 1601 & $0.37 \pm 0.12^{\mathrm{a}}$ & $0.006 \pm 0.02^{\mathrm{b}}$ & $0.617 \pm 0.31^{\mathrm{a}}$ & - \\
\hline terpinene 4-ol & 1176 & 1611 & $10.75 \pm 0.10^{\mathrm{a}}$ & $0.48 \pm 0.20^{\mathrm{b}}$ & $18.85 \pm 1.01^{\mathrm{b}}$ & $52.74 \pm 3.41^{\mathrm{a}}$ \\
\hline$\beta$ caryophyllene & 1419 & 1612 & $0.21 \pm 0.02^{\mathrm{a}}$ & $0.002 \pm 0.00^{\mathrm{b}}$ & $0.43 \pm 0.11^{\mathrm{a}}$ & $0.04 \pm 0.01^{\mathrm{b}}$ \\
\hline$\sigma$ terpineol & NI & $\mathrm{NI}$ & - & $0.005 \pm 0.01^{\mathrm{b}}$ & $0.02 \pm 0.00^{\mathrm{b}}$ & $9.53 \pm 3.01^{\mathrm{a}}$ \\
\hline$\alpha$ humulene & 1454 & 1687 & - & $0.003 \pm 0.09^{\mathrm{b}}$ & $0.184 \pm 0.01^{\mathrm{a}}$ & - \\
\hline$\alpha$ terpineol & 1189 & 1713 & $0.10 \pm 0.03^{\mathrm{b}}$ & $0.15 \pm 0.11^{\mathrm{a}}$ & $2.74 \pm 1.04^{\mathrm{a}}$ & - \\
\hline isobornylacetate & - & - & - & $0.027 \pm 0.01^{\mathrm{a}}$ & $0.374 \pm 0.21^{\mathrm{b}}$ & $0.56 \pm 0.22^{\mathrm{a}}$ \\
\hline germacrene-D & 1480 & 1726 & - & $0.003 \pm 0.02^{\mathrm{a}}$ & $0.06 \pm 0.01^{\mathrm{b}}$ & $0.12 \pm 0.01^{\mathrm{a}}$ \\
\hline$\beta$-bisabolene & 1503 & 1741 & - & $0.21 \pm 0.00^{\mathrm{a}}$ & $0.18 \pm 0.01^{\mathrm{b}}$ & $0.46 \pm 0.11^{\mathrm{a}}$ \\
\hline bicyclogermacrene & 1344 & 1705 & - & $0.003 \pm 0.02^{\mathrm{a}}$ & $0.07 \pm 0.00^{\mathrm{b}}$ & $0.12 \pm 0.07^{\mathrm{a}}$ \\
\hline neryl acetate & 1385 & 1733 & $0.36 \pm 0.04^{\mathrm{a}}$ & $0.003 \pm 0.01^{\mathrm{b}}$ & $0.011 \pm 0.01^{\mathrm{b}}$ & $0.04 \pm 0.01^{\mathrm{a}}$ \\
\hline geranyl acetate & 1383 & 1765 & $0.10 \pm 0.02^{\mathrm{b}}$ & $0.009 \pm 0.01^{\mathrm{a}}$ & $0.018 \pm 0.01^{\mathrm{b}}$ & $0.07 \pm 0.01^{\mathrm{a}}$ \\
\hline Nerol & 1228 & 1797 & - & $0.001 \pm 0.14^{\mathrm{a}}$ & - & - \\
\hline cis-piperitone & 1265 & - & - & $0.01 \pm 0.22^{\mathrm{a}}$ & $0.158 \pm 0.02^{b}$ & $0.42 \pm 0.11^{\mathrm{a}}$ \\
\hline spathulenol & 1572 & 2144 & - & $0.02 \pm 0.24^{\mathrm{a}}$ & $0.05 \pm 0.01^{\mathrm{b}}$ & $1.42 \pm 0.02^{\mathrm{a}}$ \\
\hline Eugenol & 1401 & 2030 & - & $0.23 \pm 0.03^{\mathrm{a}}$ & $0.09 \pm 0.01^{\mathrm{b}}$ & $0.28 \pm 0.11^{\mathrm{a}}$ \\
\hline Penol & & & - & - & $0.861 \pm 0.21^{\mathrm{a}}$ & $0.21 \pm 0.01^{\mathrm{b}}$ \\
\hline
\end{tabular}

Values (means of three replicates \pm SD) with different superscripts ( $\mathrm{a}-\mathrm{b})$ are significantly different at $\mathrm{P}<0.05$ between salt levels within each vegetative stage; RI retention indices relative to n-alkanes on aHP-5 and bHP-Innowax columns; not detected: Nd;not identified: $\mathrm{Ni}$

At L.V.S., the major constituents were cis sabinene hydrate $(16.33 \mu \mathrm{g} / \mathrm{g} \mathrm{DW})$ and terpinene-4ol $(10.75 \mu \mathrm{g} / \mathrm{g}$ DW) at control (Table 1). These compounds decreased significantly about 18.14 and 22.39 times with salt treatment. In addition, in the presence of $\mathrm{NaCl}$, new compounds appeared, such as camphor, $\beta$-murolene, $\alpha$-humulene, 1.8-cineole, $p$-cymene, isobornylacetate, germacrene-D, $\beta$ bisabolene, bicyclogermacrene, nerol, cispiperitone, spathulenol, eugenol, $\sigma$-terpineol. Besides, other compounds disappeared such as 
sabinene, trans $p$-menth-en-1-o and cis -sabinene hydrate.

At P.F.S., the chemotype of marjoram was cis-sabinene-hydrate and terpinene-4-ol in absence and presence of salt. These major compounds increased significantly about 3.38 and 2.79 times. In addition, salinity had a significant increase $(\mathrm{p}<0.05)$ on the content of 1.8-cineole, terpinolene, $\beta$-tujone, linalool and $\sigma$-terpineol by about 12, 5.1, 190 , 235,42 and 476.5 respectively.

According to our result it seems that chemical composition of O.majorana EO varied with physiological stage and salt treatment. Thus, according to amounts of major constituents O.majorana EOs could be divided into two chemotypes

1. At early vegetative stage, the chemotype changed from trans sabinene hydate/terpinene 4ol in the control to became sabinene/cis-sabinene hydrate at salt treatment.

2. Cis -sabinene hydrate/terpinene-4-ol characterizing the late vegetative stage and early flowering stage.

In P.F.S., the high content of one or both of these two compounds in EO followed by linalool and $\beta$-tujone, could be explained by trichomes distribution.

Some study such as Rodrigues's (2002), have reported that terpinene-4-ol was the major component flowed by $\gamma$-terpinene and cis-sabinene hydrate. In Argentinean O.majorana EOs, terpinene-4-ol and trans-sabinene hydrate seemed to be the main components (Banchio et al. 2008).

In our species and at the control, essential oil extract at the three stages delaminated contained respectively 3.963; $11.323,6.60 \mu \mathrm{g} / \mathrm{DW}$ monoterpene hydrocarbons and 22.750; 42.93, $52.04 \mu \mathrm{g} / \mathrm{DW}$ terpenes alcools. At $75 \mathrm{mM} \mathrm{NaCl}$, it contained respectively $9.168 ; 0.01 ; 27.33 \mu \mathrm{g} / \mathrm{DW}$ monoterpene hydrocarbons and $9.163 ; 0.22 ; 172.67$ $\mu \mathrm{g} / \mathrm{DW}$ terpene alcools (Table 2).

When comparing our result to some data, it seems as mentioned by Hamrouni et al. (2009) and Davaranauskaite et al. (2009) that EO yield, composition and classes could be affected by physiological stage.

The accumulation of EO during the P.F.S. could be related to ecological roles such as intensifying antifungal defences and attracting pollinators. To obtain favoured EO content, we suggest to harvest $O$. majorana at P.F.S.

To better explained the improvement in EO yield with salt and development of vegetative stage in shoots of $O$. majorana under environmental stress conditions, we accomplish a study on trichomes distribution responsible for the production of these secondary metabolites

Table 2. Chemical classes $(\mu \mathrm{g} / \mathrm{g} \mathrm{DW})$ of essential oil from Origanum majorana shoots under $\mathrm{NaCl} 75 \mathrm{mM}$ at the early vegetative stage (E.V.S), late vegetative stage (L.V.S) and flowering stage (P.F.S)

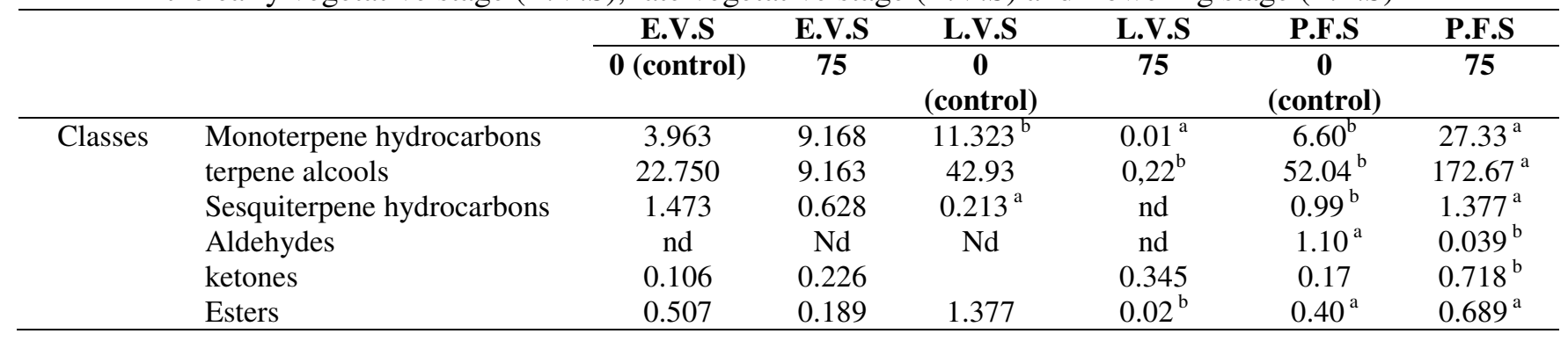

\section{Variation of trichome density with leaf age and salinity}

Origanum majorana leaf has a typical dorsiventral structure. It is composed of an heterogenous mesophyll, typical of dicotyledones; its palisade parenchyma is made of three to four layers of elongated cells. Spongy parenchyma, consists of two to three layers of cells. The leaf is caracterised by a reticulate venation. The midrib vein is surrounded by a sheath of parenchymatous cells and protected on the dorsal and ventral sides by three to four assizes of collenchymateuses cells. The leaf is enveopped by an unistratified epidermis, covered with thick cuticule. Epidermis cells were remarkably thicker on the ventral side.

As previously study at EVS by Baatour et al. (2012) has been confirmed by in this paper. In fact, all leaves of Origanum majorana L. had nonglandular and glandular trichomes on both surfaces (Figure 1: A, A'). The number of non-glandular trichomes increased at $75 \mathrm{mM} \mathrm{NaCl}$ at each vegetative stage (Figure 2). 


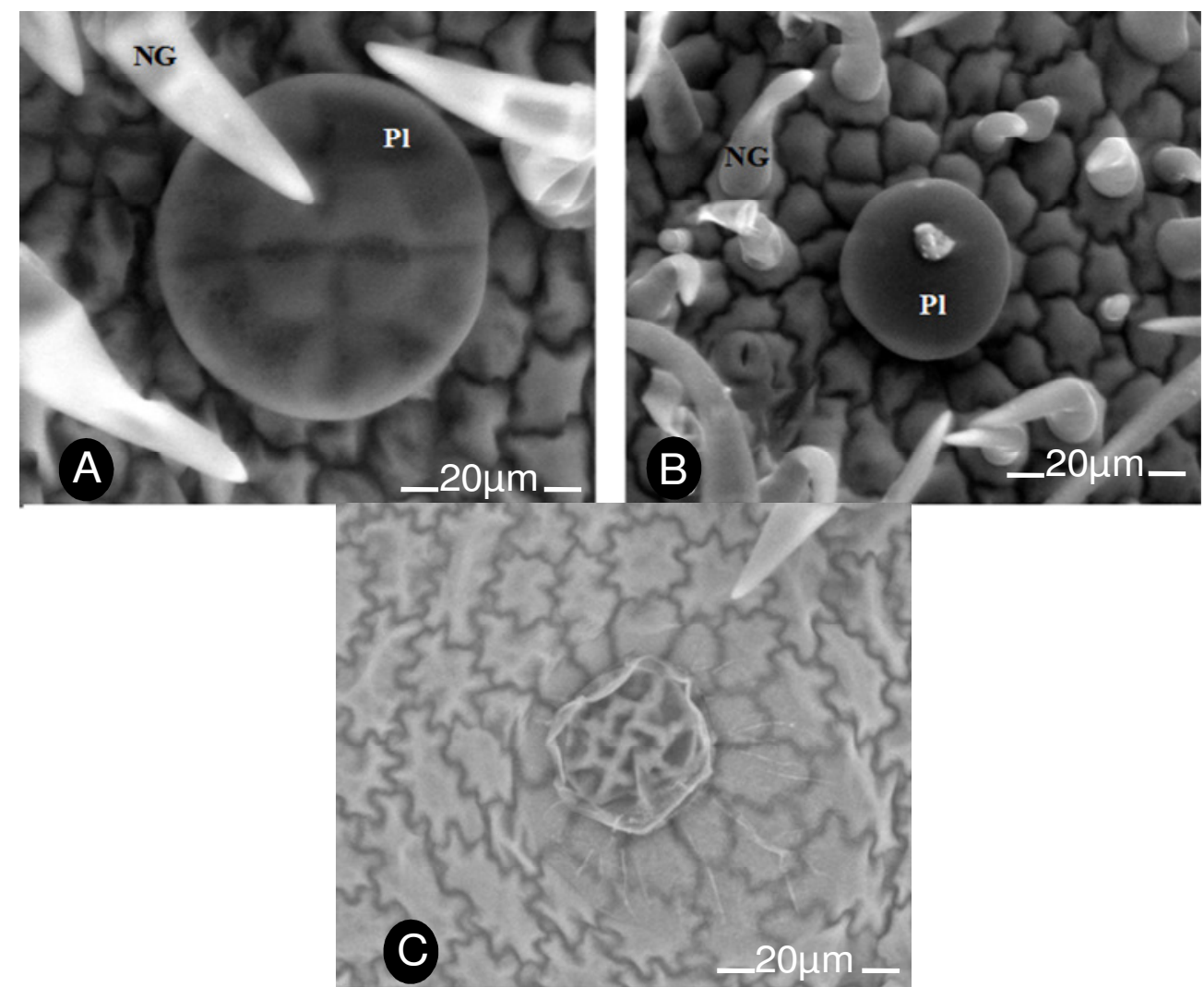

Figure 1. Scanning electron micrographs (A-C) of leaf portions from Origanum majorana L. A, trichomes on the adaxial side of a leaf; Peltate heads at eight cell stage (Pl). B, Note the higher density of nonglandular trichomes (NG) as compared with A at $75 \mathrm{mM} \mathrm{NaCl}$. C: Mature peltate trichome with torn cuticular sheath, disclosing the head cells. Bar: $1 . \mu \mathrm{m}$

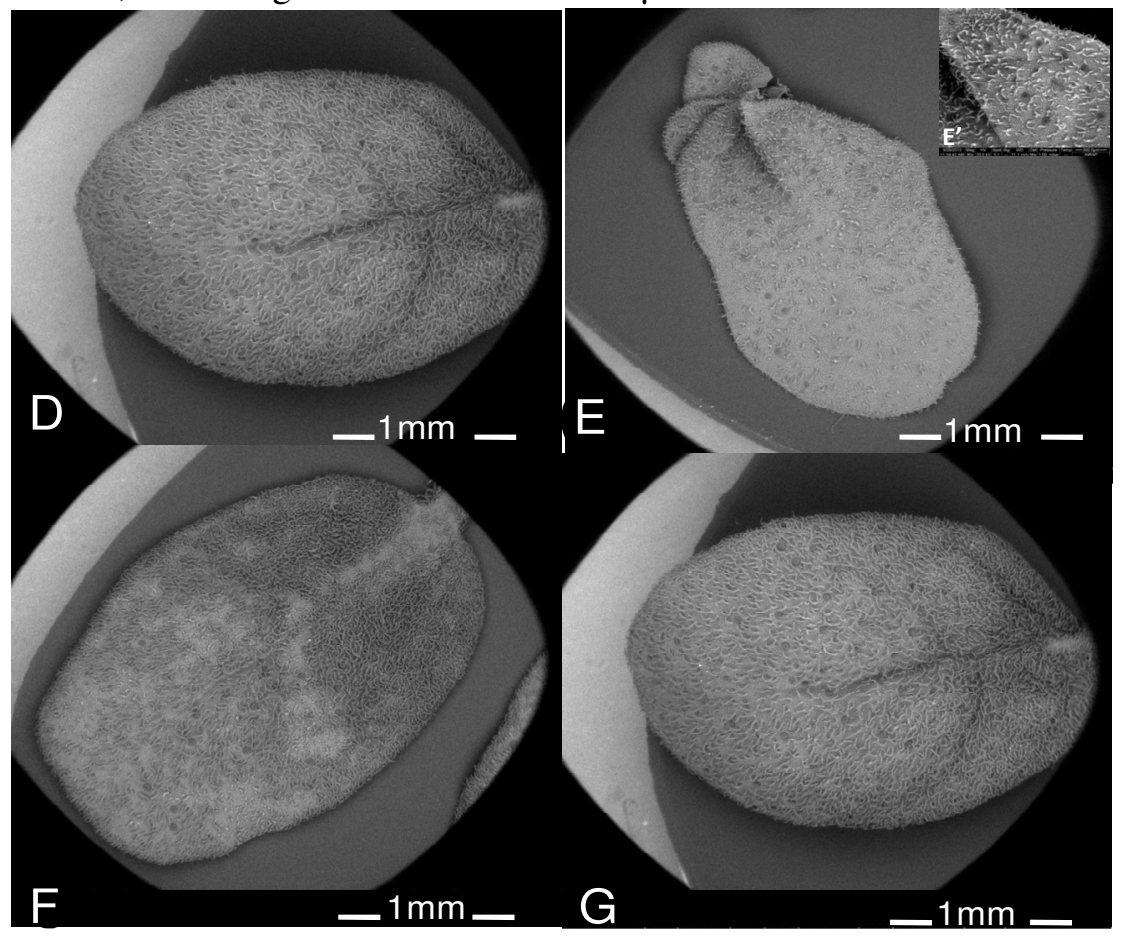

Figure 2. Scanning electron micrographs of the adaxial surfaces of Origanum majorana leaves, showing trichome density $\left(\mathrm{mm}^{-}{ }^{2}\right)$. D-F, views of early vegetative stage (E.V.S.) at $0 \mathrm{mM} \mathrm{NaCl}$; E-G, views of late vegetative stage (L.V.S.) at $75 \mathrm{mM}$. Bar $=1 \mu \mathrm{m}$ 
The density of trichomes, including nonglandular and glandular, gradually decreases with leaf maturity. The surface of young leaves is covered by important number of non glandular trichomes $\left(23 \pm 0.01^{\mathrm{c}}\right)$ and $\left(36 \pm 0.24^{\mathrm{a}}\right)$ respectively at $0 \mathrm{mM}$ and $75 \mathrm{mM} \mathrm{NaCl}$. As the leaf expands, the number and density of these trichomes decrease (Table 3).

Salinities increase the densities of the glandular trichomes at $\mathrm{EV}, \mathrm{LV}$ and $\mathrm{PF}$ stages of development to reach $\left(36 \pm 0.24^{\mathrm{a}}\right),\left(34 \pm 0.14^{\mathrm{b}}\right)$ and $\left(25 \pm 2.01^{\mathrm{c}}\right)$ respectively as compared to control $\left(23 \pm 0.01^{\mathrm{c}}\right),\left(19 \pm 0.34^{\mathrm{d}}\right)$ and $\left(9 \pm 0.14^{\mathrm{e}}\right)$.
Our result was in agreement of several studies. In fact, Gruenwald et al. (1998), affirmed that stress may increase the absolute number of glands produced before leaf emergence. In this investigation, Farooqi et al. (1999) explained the increase of their density on leaves under environmental stress conditions by the fact that salttreated plants exhibit less leaf area. The improvement of their density in M. pulegium under salt stress could explain the enhancement of EO yield.

Table. 3. Trichome density of (per $\mathrm{cm}^{-2}$ ) of leaves in Origanum majorana under $75 \mathrm{mM} \mathrm{NaCl}$ at the early vegetative stage (E.V.S.), late vegetative stage (L.V.S) and preflowering stage (P.F.S.)

\begin{tabular}{ccc}
\hline developement stage & salt treatment $(\mathrm{mM})$ & trichome density \\
\hline E.V.S & 0 & $23 \pm 0.01^{\mathrm{c}}$ \\
E.V.S & 75 & $36 \pm 0.24^{\mathrm{a}}$ \\
L.V.S & 0 & $19 \pm 0.34^{\mathrm{d}}$ \\
L.V.S & 75 & $34 \pm 0.14^{\mathrm{b}}$ \\
P.F.S & 0 & $9 \pm 0.14^{\mathrm{e}}$ \\
P.F.S & 75 & $25 \pm 2.01^{\mathrm{c}}$
\end{tabular}

Evaluated area $(0.6 \times 0.46 \mathrm{~mm})=0.276 \mathrm{~mm}^{2}$. Presented values $=$ mean $\pm \mathrm{SE}, \mathrm{n}=10$; Means in each column are separated by Duncan's multiple range test at a $5 \%$ level of probability.

In our findings, the functional role of trichomes leaf maturity becomes less important and they therefore senesce or shrivel. Our results are in agreement with Gairola et al. (2009). Other contrasting works have reported that trichomes remain functional in mature

In our result the development of stages in leaves increase the content of terpene alcools at control treatment to reach 22.75, 42.93 and 52.04 (Table. 2). The controversy was observed with salt treatment except the P.F.S. In fact the values were respectively $9.16,0.22$ and 172.67 at E.V.S, L.V.S and P.F.S at $75 \mathrm{mM}$ (Table 2).

Thus our result was contradictory or can't be explained to Meng et al. (2012), who showed that the greater number of glandular trichomes on the leaves was in relation with the higher amount of terpene substances. This is due to the fact that the glandular trichomes are the main leaf sites of terpene biosynthesis and possess a complete enzymatic equipment.

Glandular trichomes secrete various types of compounds. A growing body of experimental evidence shows that terpene biosynthesis takes place within these trichomes (SIEBERT, 2004). Terpenes usually constitute the major lipophilic components of these secretions. The secretions of glandular trichomes have been exploited by humans for a number of uses (Schilmiller et al. 2008). These secretions was previously studied with Baatour et al. (2012). There is also a general understanding that salt-stressed conditions could be favour the production of plant secondary metabolites such as essential oils and density of trichomes.

\section{CONCLUSION}

The trichome density, including nonglandular and glandular, gradually decreases with leaf maturity and increased with salinity. It seems that under salinity, young leaves are less involved in essential oil production than mature leaves. Thus to obtain favoured EO content $O$. majorana must be harvest at PFS and treated with salinity.

\section{ACKNOWLEDGEMENTS}

The authors sincerely acknowledge the responsible of greenhouse olfa in Nabeul that give me marjoram seeds. 
RESUMO: O óleo essencial (OE) de Origanum majorana L. (Lamiaceae) foi extraído, através de hidrodestilação, de plantas cultivadas sob condições controladas e salinas. A composição do óleo essencial foi determinada por GC-MS. O material vegetal foi coletado em três estádios vegetativos: precoce (EVS), tardio (L.V.S) e floração precoce (PFS). O rendimento do óleo essencial foi de 0,11\% e 0,071\% para S.V.S, 0,19\% e 0,37\% para L.V.S, $0.23 \%$ e $0,47 \%$ para P.F.S, para o controle e na presença de $\mathrm{NaCl} 75 \mathrm{mM}$, respectivamente. O estresse salino e desenvolvimento vegetativo de rendimento afetou a formação dos principais compostos: cis-sabineno hidratado terpineno4-ol. As folhas foram observadas em microscópio eletrônico de varredura (MEV), para determinar o número de tricomas. Os resultados mostraram que a densidade globular do tricoma diminui com a maturidade da folha mas aumenta com a salinidade.

PALAVRAS-CHAVE: Óleo essencial. Origanum majorana L Salinidade. Tricomas.

\section{REFERENCES}

BAÂTOUR, O.; BEN NASRI-AYACHI, M.; MAHMOUDI, H.; TARCHOUN, I.; NASSRI, N.; ZAGHDOUDI, M.; HARRATHI, J.; KADDOUR, R.; HAMDAOUI, G.; MARZOUK, B.; AND LACHAÂL, M. 2012. Essential oil amount yield and trichomes structure in marjoram (Origanum majorana L.) varieties under salt stress. Journal of Medicinal Plants Research, v. 6, n. 20, p. 3614-3623, 2012.

BAÂTOUR, O.; KADDOUR R.; AIDI, W. W.; LAACHÂL, M.; MARZOUK, B. Salt effects on the growth, mineral nutrition, essential oil yield and composition of marjoram (Origanum majorana). Acta Physiol Plantarum, v. 32, p. 45-5, 2010. http://dx.doi.org/10.1007/s11738-009-0374-4

BANCHIO, E.; BOGINO, P. C.; ZYGADLO, J.; GIORDANO, W. Plant growth promotingrhizobacteria improve growth and essential oil yield in Origanum majorana L. Biochem Syst Ecol, v. 36, v. 66-77, 2008.

DAVARANAUSKAITE, A. ; VENSKUTONIS, P. R.; RAYNAUD, C.; TALOU T VISSKELIS, P. SASNAUSKAS, C. Variations in the essential oil composition in buds of six blackcurrant (Ribes nigrum L.) cultivars at various development phases. Food Chemistry, v. 114, p. 671-679, 2009.

http://dx.doi.org/10.1016/j.foodchem.2008.10.005

FAROOQI, A. H. A.; SANGWAN, N.S.; SANGWAN, R. S. Effect of different photoperiodic regimes on growth, flowering and essential oil in Mentha species. Plant Growth Regul, v. 29, p. 181-187, 1999. http://dx.doi.org/10.1023/A:1006248019007

FILIPPO-DANTUONO, L.; GALLETTI, G. C.; BOCCHINI, P. Variability of essential oil content and composition of Origanum vulgare L. populations from a north mediterranean area (Liguria Region, Northern Italy). Annals of Botany, v. 86, p. 471-478, 2000. http://dx.doi.org/10.1006/anbo.2000.1205

GAIROLA, S., NAIDOO, Y., BHATT, A., NICHOLAS, A. An investigation of the foliar trichomes of Tetradenia riparia (Hochst.) Codd [Lamiaceae]: An important medicinal plant of Southern Africa. Flora, v. 204, p. 325-330, 2009. http://dx.doi.org/10.1016/j.flora.2008.04.002

GRUENWALD, J.; BRENDLER, T.; JAENICKE, C. PDR for Herbal Medicines. Medical Economic Company, Montvale, NJ, p. 975-976, 1998.

HACHICHA, M. Les sols salés et leur mise en valeur en Tunisie. Sécheresse, v. 18, n. 1, p. 45-50, 2007.

HAMROUNI, S. I.; MAAMOURI, E.; CHAHED, T.; AIDI, W. W.; KCHOUK, M. I.; MARZOUK, B. Effect of growth stage on the content and composition of the essential oil and phenolic fraction of sweet marjoram (Origanum majorana L.). Industrial Crops and Products, v. 30, p. 395-402, 2009.

http://dx.doi.org/10.1016/j.indcrop.2009.07.010 
HEUER, B.; YANIV, Z.; RAVINA, I. Effect of late salinization of chia (Salvia hispanica), stock (Matthiola tricuspidata) and evening primrose (Oenothera biennis) on their oil content and quality. Industrial Crops and Products, v. 15, p. 163-16, 2002. http://dx.doi.org/10.1016/S0926-6690(01)00107-8

KARRAY-BOURAOUIA, N.; MOKDED RABHIB.; NEFFATI, MANEL.; BARBARA, BALDAND.; ANNAMARIA, RANIERIE.; KIM, N.S., LEE, D. S., 2004. Headspace solid-phase microextraction for char acterization of fragrances of lemon verbena (Aloysia triphylla) by gas chromatography-mass spectrometry. $\mathbf{J}$ Sep Sci, v. 27, p. 96-100. http://dx.doi.org/10.1002/jssc.200301603

MARZOUK, B.; LACHAÂL, M; SMAOUIB, A. 2008. Salt effect on yield and composition of shoot essential oil and trichome morphology and density on leaves of Mentha pulegium. Industrial Crops and Products, v. 30, p. 338-343.

MENG-QI, L.; ZHEN-WEN, L.; JING, Z. Morphology and histochemistry of the glandular trichomes of Isodon rubescens (Hemsley) H. Hara [Lamiaceae]: A promising medicinal plant of China. Journal of Medicinal Plants Research, v. 6, n. 8, p. 1455-1460. 2012. http://dx.doi.org/10.5897/jmpr11.409

MOHAMMED, N.; YASMEN SH.; AND NOHIR G. Antimicrobial activity of water and ethanol Marjoram (Origanum marjorana L.) extract. The 6th Arab and 3rd International Annual Scientific Conference on: Development of Higher Specific Education Programs in Egypt and the Arab World in the Light of Knowledge Era Requirements Faculty of Specific Education Mansoura University-Egypt, v. 13-14, p. 2350-2366, 2011.

MSAADA, K.; HOSNI, K.; BEN TAARIT, M.; CHAHED, T.; KCHOUK, M.E.; MARZOUK B. Changes on essential oil composition of coriander (Coriandrum sativum L.) fruits during three stages of maturity. Food Chemistry, v. 102, p. 1131-1134. 2007. http://dx.doi.org/10.1016/j.foodchem.2006.06.046

NOVAK, J.; BITSCH, C.; LANGBEHN, J.; PANK, F, S.; M AND GOTSIOU, Y.; et al. Ratios of cis- and trans-sabinene hydrate in Origanum majorana L. and Origanum microphyllum (Bentham) Vogel. Biochemical Systematics and Ecology, v. 28, p. 697-704, 2000.

PIMPLE, B. P.; KADAM, P. V.; PATIL, M. J. 2012. Ulcer healing properties of different extracts of Origanum majorana in streptozotocin -nicotinamide induced diabetic rats. Asian Pacific Journal of Tropical Disease, v. 2, n. 4, p. 312-318. http://dx.doi.org/10.1016/S2222-1808(12)60068-1

PIMPLE, B. P.; KADAM, P. V.; PATIL, M. J. Comparative antihyperglycaemic and antihyperlipidemic effect of Origanum majorana extracts in NIDDM Rats. Oriental Pharmacy and Experimental Medicine, v. 12, n. 1, p. 41-50, 2012. http://dx.doi.org/10.1007/s13596-011-0047-x

SCHILMILLER, A. L.; LAST, R. L.; PICHERSKY, E. 2008. Harnessing plant trichome biochemistry for the production of useful compounds. Plant Journal, v. 54, p. 702-711. http://dx.doi.org/10.1111/j.1365313X.2008.03432.x

SIEBERT, D. J.; Localization of Salvinorin A and Related Compounds in Glandular Trichomes of the Psychoactive Sage, Salvia divinorum. Annals of Botany, v. 93, p. 763-771.

http://dx.doi.org/10.1093/aob/mch089

VERDIAN-RIZI., 2008. Phenological variation of Laurus nobilis L. Essential oil from Iran. EJEAFChe, v. 7 , p. 3321-3325, 2004.

WAGNER, G. J.; WANG.; E.; SHEPHERD, R. W. New approaches for studying and exploiting on old protuberance, the plant trichomes. Annals of Botany, v. 93, p. 3-11, 2004.

http://dx.doi.org/10.1093/aob/mch011 